\title{
Asas Penyelenggaraan Sistem Jaminan Sosial Nasional Oleh Badan Penyelenggara Jaminan Sosial (BPJS) Kesehatan di Kota Jambi
}

\author{
Pahlefi $^{1 *}$, Nelli Herlina ${ }^{2}$, Herlina Manik ${ }^{3}$ \\ 1,2,3 Fakultas Hukum, Universitas Jambi, Indonesia \\ Jl. Raya Jambi-Muara Bulian Km. 15, Mendalo Indah, Muaro Jambi, Jambi \\ *Correspondence Email: pahlefi@unja.ac.id; Nelliherlina@unja.ac.id; Herlina_manik@unja.ac.id
}

\begin{abstract}
Abstrak. Artikel ini merupakan hasil penelitian dengan tujuan untuk menganalisis dan mengkaji tentang asas-asas dalam penyelenggaraan Sistem Jaminan Sosial Nasional oleh BPJS Kesehatan di Kota Jambi. Kemudian bertujuan untuk mengkaji dan menganalisis tentang permasalahan dan upaya mengatasi permasalahannya. Penelitian yang dilakukan merupakan jenis penelitian empirik, yang berkonsentrasi terhadap data pokok dari lapangan. Metode pengambilan sampel adalah melalui teknik 'accidental sampling'. Hasil penelitian menyebutkan bahwa asas kemanusiaan dan asas manfaat sebagian besar telah terlaksana dalam pelayanan BPJS di Rumah Sakit di Kota Jambi. Hanya Asas keadilan sosial bagi seluruh rakyat Indonesia sebenarnya masih mengalami kekaburan dan belum nampak pelaksanaannya pada pelaksanaan layanan kesehatan oleh BPJS di Rumah Sakit Kota Jambi. Selanjutnya masih terdapat permasalahan dalam penyelenggaraan BPJS di Kota Jambi, yaitu sebagian di antaranya kerugian pada pelaksanaan Jaminan Kesehatan Nasional, ketidakadilan klaim peserta pada kelompok - kelompok tertentu, tidak meratanya fasilitas dan tenaga kesehatan di Rumah Sakit-Rumah Sakit.
\end{abstract}

Kata Kunci: Asas; Sistem Jaminan Sosial Nasional

\begin{abstract}
This article is the result of research with the aim of analyzing and examining the principles in the implementation of the National Social Security System by BPJS Kesehatan in Jambi City. Then it aims to study and analyze the problems and efforts to overcome the problems. The research carried out is a type of empirical research, which concentrates on the main data from the field. The sampling method is through the 'accidental sampling' technique. The result of the research states that the humanitarian principle and the principle of benefit have mostly been implemented in BPJS services at the Hospital in Jambi City. Only the principle of social justice for all Indonesian people is still obscured and its implementation has not yet been seen in the implementation of health services by BPJS at Jambi City Hospital. Furthermore, there are still problems in the implementation of the BPJS in Jambi City, namely some of the losses in the implementation of the National Health Insurance, the unfairness of claims by participants in certain groups, unequal facilities and health workers in Hospitals.
\end{abstract}

Keywords: Principle; National Social Security System

\section{PENDAHULUAN}

Badan Penyelenggara Jaminan Sosial (BPJS) Kesehatan dan Ketenagakerjaan merupakan dua badan yang tergabung dalam BPJS Nasional, yang memiliki maksud adalah terselenggaranya perlindungan hak asasi bangsa untuk memperoleh rasa sehat. BPJS kesehatan dalam tulisan ini merupakan serta fokus diskursus, dimana masalah kesehatan merupakan cakupan dari proteksi dalam program Jaminan Kesehatan Nasional atau di singkat JKN. Masyarakat, peserta yang telah mmberikan iuran baik secara mandiri ataupun atas biaya dari pemerintah, berhak atas manfaat dari perlindungan kesehatan, yang merupakan kebutuhan pokok dari hidup manusia. ${ }^{1}$

Sejak di jalankannnya program Jaminan Kesehatan Nasional, Badan Penyelenggara Jaminan Sosial secara beruntut menganlami defisit. Reportase finansial Badan Penyelenggara Jaminan Sosial menyebutkan dalam tahun 2017 mendapati penurunan secara finansial hingga menggapai angka kurang lebih seratus delapan puluh milliar rupiah lebih. Pada bulan kelima di tahun 2018 penurunan secara finansial Badan Penyelenggara Jaminan Sosial telah mencapai angka lebih dari empat triliun rupiah, yang mana penghasilan Badan Penyelenggara Jaminan Sosial sebesar lebih dari tiga puluh tiga triliun rupiah, akan tetapi biaya yang telah dikeluarkan sebesar tiga puluh delapan triliunrupiah. ${ }^{2}$ Penurunan pendapatan BPJS dapat lebih banyak lagi apabila belum ada usaha pembenahan menuju hal yng lebih baik belum cepat-cepat diupayakan. Selanjutnya diprediksi kerugian BPJS bisa diprediksi menembus angka Rp 39,5 triliun di tahun dua ribu dua puluh. ${ }^{3}$ Namun di bulan Maret tahun dua ribu dua puluh satu BPJS mengalami

${ }^{1}$ Pasal 1 Angka 1 Peraturan Presiden Nomor: 12 Tahun 2013 Tentang Jaminan Kesehatan.

2“Banyaknya Masalah Dalam Pelaksanaan JKN, Tindakan Pemerintah? Halaman All - Kompasiana.Com,” accessed February 24, 2020, https://www.kompasiana.com/hananisrina/5c1a8ab6ab12ae70d11c5ac3/banyak-nya-pr-dalam-pelaksanaanjkn-tindakan-pemerintah?page=all\#.

3 Jambi Independent, "Utang BPJS Kesehatan Membeludak," JAMBIINDEPENDENT.COM, accessed February 24, 2020, https://www.jambi-independent.co.id/read/2019/11/07/44537/utang-bpjs-kesehatan-membeludak. 
surplus keuangan mencapai angka 18 Trilyun. ${ }^{4}$ Fluktuasi keuangan yang di alami oleh BPJS memberikan gambaran bahwa ada permasalahan dalam manajemen perusahaan ataupun hal lainnya.

Keanggotaan yang menjadi peserta Badan Penyelenggara Jaminan Sosial berdasarkan beberapa opini juga turut memberikan andil pada masalah-masalah yangmana dialami pada Badan Penyelenggara Jaminan Sosial pada umumnya. Pelaksanaan nyata keikutsertaan JKN Provinsi Jambi sejumlah lebih dari tujuh puluh persen. Berdasarkan 3,4 juta jumlah masyarakat Provinsi Jambi, lebih dari lina puluh persen atau lebih dari satu juta masyarakat Jambi telah dicatat menjadi anggota Jaminan Kesehatan Nasional. ${ }^{5}$

Dengan mengamati dari banyak sumber pemberitaan, problem tata kelola menjadi sebab paling sering muncuk ke permukaan. Misalnya adalah terkait dengan permasalahan rasa adil dalam teknis penyelenggaraan program jaminan sosial, sampai kepada permasalahan fasilitas dan sumberdaya kesehatan yang tidak sama dki tiap daerah, baik dari segi kuantitas maupun kualitas.

Pertanyaan yang muncul kemudian adalah apakah permasalahan-permasalahan yang di alami oleh Badan Penyelenggara Jaminan Sosial tersebut di atas merupakan permasalahan yang di akibatkan hanya semata-mata dari tata kelola saja, ataukah dari aspek pengaturan, misalnya asas dalam undang-undang, mempunyai peran yang cukup signifikan terhadap hal tersebut di atas. Ketidaksinkronan antara penerapan asas dalam aspek empirisnya dikaitkan terhadap ketentuan-ketentuan yang terdapat dalam peraturan perundang-undangan, patut di duga merupakan salah satu penyebab masalah-masalah yang di alamai oleh Badan Penyelenggara Jaminan Sosial.

Memahami tentang penjabaran sebagaimana tersebut di atas, oleh karena itu penulis melalui artikel ini ingin membahas tentang permasalahan penyelenggaraan System Jaminan Sosial Nasional dalam Jaminan Kesehatan Nasional di Kota Jambi khususnya dan Indonesia pada umumnya. Selanjutnya juga penulis berusaha membahas tentang apakah penyelenggaraan system jaminan sosial nasional oleh BPJS kesehatan telah menggambarkan asas-asas penyelenggaraan sistem jaminan sosial nasional sebagaimana telah di atur dalam Undang-Undang tentang BPJS.

\section{METODE}

Tulisan dalam artikel ini adalah penelitian empiris, yang menitik beratkan pada data utama yang berasal dari tataran praktis.

Lebih rinci lagi bahwa penelitian ini adalah bersifat penelitian yang mendeskripsikan secara jelas, terperinci serta sistematis mengenai permasalahan yang di kaji. Riset dengan sifat penelitian tersebut dibuat merupakan usaha dalam mengkaji dengan lugas serta riil, yang di susun menurut susunan secara sistematis dalam melihat implementasi asas-asas hukum dalam penyelenggaraan jaminan sosial nasional oleh BPJS.

Aspek-aspek kajian primer dalam artikel ini berasal dari penelitian lapangan dengan teknis wawancara yang di lakukan pada fasilitas kesehatan yang terdapat di Kota Jambi, yang masih menjali kerjasama dengan Badan penyelenggara Jaminan Sosial Jambi. Selain BPJS Jambi yang menjadi informan, responden di tentukan dengan menggunakan teknik accidental sampling, yang di lakukan dengan cara yaitu:

1. Eksplorasi sampling dengan langsung, penulis menyelenggarakan eksplorasi dengan memohon ketersediaan data pihak ketiga.

2. Teknik wawancara dengan menggunakan alat riset yang terdiri atas serangkaian pertanyaan tertulis, baik dengan berhadapan langsung dengan responden maupun dengan teknis jejak pendapat di media elektronik.

Aspek kajian sekunder dalam riset ini juga menjadi bagian pending dalam menganalisis permasalahan yang di tampilkan. Aspek kajian tersebut berasal dari bahan-bahan dokumen yang tertulis yang terdiri dari:

1. UUD 1945

2. Undang-Undang Tentang Sistem Jaminan Sosial Nasional.

3. Undang-Undang Tentang Badan Penyelenggara Jaminan Sosial.

4. Peraturan Pemerintah yang terkait dengan BPJS dan Jaminan Kesehatan; dan

5. Index dibidang hukum kamus hukum, jurnal di bidang hukum, serta kamus bahasa Indonesia.

\footnotetext{
${ }^{4}$ https://www.cnbcindonesia.com/news/20210214114224-4-223180/bpjs-kesehatan-surplus-rp-187-t-ini-besaran-iuran2021.

5 "Kepesertaan JKN Jambi 1,7 Juta Jiwa, BPJS Kesehatan Apresiasi Pemda Yang Daftarkan Penduduknya-Tribun Jambi," accessed February 24, 2020, https://jambi.tribunnews.com/2019/12/02/kepesertaan-jkn-jambi-17-juta-jiwa-bpjs-kesehatanapresiasi-pemda-yang-daftarkan-penduduknya\#.
} 
HASIL DAN PEMBAHASAN

\section{Permasalahan Penyelenggaraan System Jaminan Sosial Nasional Dalam Jaminan Kesehatan Nasional Di Kota Jambi Khususnya Dan Indonesia Pada Umumnya}

Berdasarkan hasil penelitian di dapatkan bahwa kendala di dapat dari mayoritas angoota. Hal ini di sebabkan belum terdapat pemahaman mengenai prosedur yang perlu di lalui oada waktu melakukan pemeriksaan kesehatan untuk pribadi maupun anggota keluarganya menggunakan kartu kesehatan dari BPJS. Penduduk memilik anggpana bahwa ketika pembayaran telah di lakukan maka tidak perlu lagi untuk membayar pada priode selanjutnya. Di samping hal ini juga mengenai adanya ketidak fahaman tentang proses penunjukan fasilitas kesehatan selanjutnya dalam penanganan penyakit.

Mengenai standar atau tolak ukur pelayanan kesehatan, terdapat tiga jenis tolak ukur yang dikenal yakni: ${ }^{6}$

1. Tolak ukur sacara struktural, yaitu sumber daya manusia, uang, material, peralatan, dan mesin.

2. Tolak ukur secara proses, yakni tahapan kegiatan yang dilakukan dalam pelayanan.

3. Tolak ukur dari aspek hasil, yakni hasil-hasil (outcome) yang diharapkan

Menurut apa yang tertulis tersebut bahwa standar/tolak ukur yang dilakukan oleh pihak fasilitas kesehatan tingkat pertama (puskesmas) bukan seluruhnya di laksanakan, semestinya pada saat puskesmas membuat rujukan ke rumah sakit maka mesti terdapat rangkaian tindakan dan putusan tegas pada rumah sakit apakah rumahsakit tersebut menyatakan sedia dan bisa menyelenggarakan layanan kesehatan secara baik, sehingga perlindungan pasien itu dapat terjamin.

Besarnya animo penduduk Indonesia terhadap layanan kesehatan belum di imbangi pada upaya meningkatkan layanan kesehatan. Mutu layanan kesehatan mengacu pada level keutamaan performa layanan kesehatan yang bisa memberika kepuasan pada tiap pengguna layanan kesehatan yang seimbang dengan level rasa puas rerata masyarakat, prosedur pelaksanaannya berdasarkan patokan dan kode etik profesi yang sudah dirumuskan. ${ }^{7}$ Agar bisa memuaskan, maka terdapat perihal-perihal utama dan urgen yang merupakan fokus dalam hal ini yaitu didasarkan pada kepentingan penduduk, yang mana hal ini akan berdampak pada berkembangnya layanan kesehatan. Hal ini secara garis besanrnya di pengaruhi oleh besar-kecilnya suatu kebutuhan dan tuntutan dari penduduk yang pada dasarnya adalah deskripsi dari problem kesehatan yang dihadapi penduduk tersebut. Mengenai kebutuhan mendesak tentang kesehatan adalah sesuatu bersifat subjektif, sehingga upaya memenuhi akan tuntutan kesehatan memiliki level yang kecil implikasinya pada pergeseran level kesehatan, karena sifatnya yang subjektif, maka tuntutan terhadap kesehatan tergantung dari kedudukan sosial penduduk itu sendiri.

Pelaksanaan program JKN termasuk di Kota Jambi memang di jumpai beberapa permasalahan. Hal ini dapat di rinci sebagai berikut:

1. Kerugian keuangan dalam penyelenggaraan Jaminan Kesehatan Nasional;

2. Rasa tidak adil perihal pelayanan terhadap anggota pada golongab-golongan tertentu;

3. Tidak terdapatnya pemerataan sumberdaya fisik dan manusia di Rumah Sakit yang ada yang kuantitas sumber daya fisik dan manusia di bidang kesehatannya lumayan besar dan di wilayah yang terpencil kuantitasnya kecil sekali.

Ketika diselenggarkan JKN di tahun 2014, BPJS menderita kerugian secara simultan. Hingga sekarang persoalan dari aspek finansial menjadi warna penyelenggaraan Jaminan Kesehatan Nasional. Catatan finansial BPJS Kesehatan di dapati bahwa tahun 2017 mendapat defisit sebesar lebih dari seratus delapan puluh milliar rupiah. Pada bulan kelima tahun dua ribu delapan belas defisit Badan Penyelenggara Jaminan Sosial kesehatan telah menjangkau lebih dari empat puluh delapan triliun rupiah, dengan pengasilan BPJS Kesehatan sebesar lebih dari tiga puluh tiga triliun rupiah, akan tetapi biaya yang dikeluarkan telah menembus angka lebih dari tiga puluh delapan triliun rupiah.

Kemudian mengenai penyebaran secara komprehensif mengenai potensi kemampuan fisik serta manusia di bidang kesehatan di wilayah negara Indonesia merupakan permasalahan yang tidak kunjung selesai. Pada daerah tertentu seperti wilayah Indonesia Timur masih di jumpai minimnya sumberdaya fisik dan manusia di bidang kesehatan. Akan tetapi berbeda kondisinya ketika melihat penyeberannya di wilayah pulau jawa, dimana fasilitas kesehatan terus bertambah seiring terpusatnya pertumbuhan penduduk di pulau jawa. Hal ini berimplikasi kepada minimnya kemampuan anggota Jamiman Kesehatan Nasional mendapatkan manfaat Jaminan Kesehatan nasional sebagai akibat minimnya sumber daya fisik dan manusia di wilayah tersebut.

Perlunya pemangku kebijakan untuk selalu mengevaluasi penyelenggaraan Jaminan Kesehatan Nasional secara periodik. Selanjutnya ditindaklanjuti dengan penerbitan kebijakan yang memihak kepada wilayah yang penduduknya sulit mengakses fasilitas kesehatan dan sumber daya kesehatan. Hal ini merupakan upaya untuk memaksimalkan penyelenggaraan Jaminan Kesehatan Nasional di seluruh wilayah Indonesia.

\footnotetext{
${ }^{6}$ Tjahjono Koentjoro, Regulasi Kesehatan di Indonesia,(Yogyakarta: ANDI OFFSET, 2007), hlm. 26

${ }^{7}$ Azwar, Azrul. Program Menjaga Mutu Pelayanan Kesehatan. Jakarta: Yayasan Penerbitan IDI,1994, hlm. 3.
} 
Pembiayaan Jaminan Kesehatan Nasional juga menjadi hal yang sangat urgen untuk ditinjau kembali sebagau upaya re-orientasi pembangunan di bidang kesehatan. Perlu adanya revitalisasi orientasi program Jaminan Kesehatan Nasional dalam bentuk revitalisasi akses informasi yang adil kepada seluruh anggota BPJS Kesehatan. Regulasi pelaksanaan JKN adalah suatu hal yang paling utama di samping hal tersebut di atas, karena regulasi merupakan salah satu akar masalah yang menyangkut keadilan sosial dalam aspek kesehatan.

Terkait dengan hal tersebut, di butuhkan suatu usaha untuk mempertimbangkan kembali terhadap tarif nyata yang terdapat pada fasilitas kesehatan. Bukan selayaknya sistem pembiayaan yang belum selesai menjadi taruhan atas mutu layanan kesehatan. Pihak pemangku kebijakan semestinya mendudukan profesi di bidang kesehatan dalam suatu forum untuk membicarakan secara serius masalah yang ada.

Orientasi kebijakan di bidang Jaminan Kesehatan semestinya memihak golongan masyarakat yang kurang mampu, karena golongan ini sampai saat ini menduduki jumlah yang cukup besar di Indonesia

\section{Asas-Asas Penyelenggaraan Sistem Jaminan Sosial Nasional Oleh BPJS Kesehatan Di Kota Jambi}

Pasal 2 Undang-Undang Nomor 24 Tahun 2011 tentang Badan Penyelenggara Jaminan Sosial, mengatur bahwa penyelenggaraan jaminan sosial oleh BPJS di dasarkan pada 3 asas, yaitu:

1. Asas kemanusiaan;

Asas kemanusiaan adalah asas yang terkait dengan penghargaan terhadap martabat manusia. Dalam arti lain adalah dengan tidak melihat dan mempertimbangkan kedudukan atau tingkatan sosial, kedudukan politik, suku, kepercayaan, keyakinan ataupun hal lain yang berkaitan dengan hal tersebut.

2. Asas Manfaat;

Makna dari asas ini adalah terkait dengan teknis pelaksanaan dalam penyelenggaraan susuatu yang tepat guna dan berhasil guna, serta tidak membuang-buang waktu dan biaya.

3. Asas keadilan sosial bagi seluruh rakyat Indonesia.

Pengertian asas ini dalam beberapa referensi tidak di temukan secara rinci, akan tetapi dalam penjelasan undangundang asas tersebut di sebutkan sebagai asas yang bersifat idiil.

Maksud implementasi dari asas kemanusiaan adalah sudut pandang berawal dari pemahaman bahwa manusia adalah pribadi berdiri sendiri atau individual, dimana statusnya dalam lingkungan sosial merupakan pribadi yang berdiri sendiri dan kemerdekaan serta hak asasi atas jasmani dan rohaninya. Manusia secara hakiki adalah makhluk hidup yang hidup secara berkelompok yang mutlak baru mendapatkan eksistensinya apabila bersama-sama dengan individu manusia yang lainnya, yang di dalam kehidupannya dituntut untuk hidup secara tertib dan saling menjaga satu sama lainnya. ${ }^{8}$

Hak dan kewajiban peserta Badan Penyelenggara Jaminan Sosial tidak hanya di pandang sebatas kepesertaanya, akan tetapi sebagai pasien pengguna dan penikmat fasilitas kesehatan semestinya di lihat dari sudut pandang hakhaknya dari sudut pandang hak asasi manusia. Sebagai permasalahan yang lebih lugas, bahwa pelayanan terhadap pengguna fasilitas kesehatan oleh peserta BPJS, pelayanan secara manusiawi harus diberikan secara seimbang tanpa melihat kelas, dan strata sosial kemasyarakatan. Hal tersebut di dukung oleh ketentuan dalam Konstitusi Republik Indonesia yang mengatur mengenai kesetaraan kehidupan sejahtera secara jasmani dan rohani, kebutuhan sekunder, kelayakan hidup sehat, dan pelayanan atas hak hidup sehat. ${ }^{9}$

Implementasi asas Kemanusiaan dalam pelayanan di Kota Jambi bisa di lihat dalam proses interview terhadap responden penelitian yang mana di bagi dalam 2 hal, yaitu aspek berkaitan dengan pengelolaan dan penyelenggaraan Badan Penyelenggara Jaminan Sosial bidang kesehatan, serta kepesertaan masyarakat dalam program Badan Penyelenggara Jaminan Sosial bidang kesehatan yang di ambil dari sumber yang bisa di interview.

1. Berkaitan dengan tata cara registrasi untuk anggota Badan Penyelenggara Jaminan Sosial bidang kesehatan yang mana melakukan pemeriksaan badannya pada Fasilitas Kesehatan di Kota Jambi maka peneliti melakukan wawancara dengan responden sebagai pemegang Program BPJS menyebutkan bahwa tata cara registrasinya tidak terlalu mengalami kesulitan yang berarti. Masyarakat hanya mendatangi BPJS guna melakukan registrasi menjadi anggota BPJS. Akan tetapi ada sebagian masyarakat di Kota Jambi yang di wawancarai mengatakan bahwa di karenakan pendaftarannya harus melalui Kantor BPJS dan harus menunggu dalam antrian yang panjang, sehingga dapat memakan waktu berhari-hari. Apalagi jika dalam kondisi pandemic Covid-19.

2. Selanjutnya berkaitan dengan standarisasi pelayanan Puskesmas terhadap peserta BPJS Kesehatan, beberapa kutipan wawancara yang penulis rangkum yaitu sebagai berikut:

\footnotetext{
${ }^{8}$ A. Masyhur effendi, HAM Dalam/Dinamika Yuridis, Sosial, Politik, (Bogor: Ghalia Indonesia, 2010), hlm.68

${ }^{9}$ Lihat Pasal $28(\mathrm{H})$ ayat (1) UUD 1945.
} 
Pahlefi, Nelli Herlina dan Herlina Manik, Asas Penyelenggaraan Sistem Jaminan Sosial Nasional Oleh Badan Penyelenggara Jaminan Sosial (BPJS) Kesehatan di Kota Jambi

Patokannya tidak ada bedanya dengan pengguna fasillitas kesehatan secara umum serta tanpa mengadakan pembedaan pelayanan antara pengguna antara pengguna fasilitas kesehatan yang ada. Fakta yang terlihat adalah pada sebagian kecil fasilitas kesehatan terdapat kuantitas ruangan rawat yang tidak seimbang dengan banyak masyarakat pengguna fasilitas kesehatan yang membutuhkan ruang rawat inap. Selain itu adalah bahwa pelayanan terhadap anggota Badan Penyelenggara Jaminan Sosial dilakukan berdasarkan tingkat pelayanan yang dipilih oleh anggota dengan berdasarkan kemampuan membayar iuran yang di tetapkan. ${ }^{10}$

Asas ke-manusiaan pada pelayanan fasilitas kesehatan sudah terwujud berdasarkan eksplorasi empirik dalam bentuk upaya melayani pengguna fasilitas kesehatan tanpa adanya diskriminasi antara anggota BPJS maupun non anggota BPJS, akan tetapi tetap mengacu kepada ketentuan standar operasional prosedur dari BPJS. Ragam sistem layanan untuk pengguna fasilitas kesehatan terdapat dalam 2 macam yaitu medical sevices (layanan medis) dan layanan rawat inap serta ambulan, dimana ambulan diperuntukkan bagi pengguna fasilitas kesehatan yang merupakan pengguna faskes yang di tunjuk (dirujuk) dari faskes men menurut suatu situasi yangmana telah di atur oleh BPJS.

Berdasarkan ketentuan hukum tentang Sistem Jaminan Sosial Nasioal, layanan kesehatan terdiri dari :

1. Penyuluhan Kesehatan;

2. Imunisasi;

3. Pelayanan KB;

4. Rawat Jalan;

5. Rawat Inap;

6. Unit Gawat Darurat; dan

7. Layanan kesehatan lainnya termasuk cuci darah dan jantung. ${ }^{11}$

Layanan sebagaimana disebutkan di atas harus diselenggarakan berdasarkan standar layanan secara optimal, yang merupakan tindakan dalam kerangka memastikan keberlanjutan penyelenggaraan sistem jaminan sosial, termasuk menjamin tingkat rasa puas anggota sistem jaminan sosial. Sifat layanan di buat secara fleksibel dengan menyesuaikan dan beradaptasi tingkat urgensi kepentingan dan permintaan anggota akan layanan pada fasilitas kesehatan, sehingga dapat mengalami perubahan, akan tetapi tetap di dasarkan atas daya dukung finansial dari BPJS.

Berdasarkan hasil temuan penelitian di kaitkan dengan asas manfaat, bisa difahami jika anggota Jaminan Soaial di bidang kesehatan dalam kelompok Penerima Bantuan Iuran (PBI) kuantitasnya lumayan banyak. Selain hal itu, dari aspek tingkat edukasi berada dalam level yang cukup rendah. Hal ini akan berpengaruh kepada level pekerjaan yang di geluti, yang sangat sulit untuk mendapatkan pekerjaan yang masuk dalam standar layak dan tetap. Mayoritas anggota layanan jaminan kesehatan adalah berada disektor informasl dan domestik. Hal ini dapat mendeskripsikan lebih luas tentang dampak yang lebih dalam badan (BPJS) terhadap layanan kesehatan kepada penduduk di bawah garis kesejahteraan.

Implikasi yang mendalam atas implementasi JKN pada BPJS Kesehatan terhadap penduduk pra-sejahtera bisa di amati pada lebih dari satu ukuran, yaitu: mutu; apresiasi negara lain; kesiapan; dorongan; fleksibilitas penyesuaian diri terhadap situasi dan kondisi lingkungan; dan kemampuan beradaptasi dengan visi lembaga. Fakta secara empiris dapat di katakan bahwa tidak sedikit objek penelitian yang tidak faham secara benar mengenai tata cara registrasi dan kegunaan dari kartu BPJS kesehatan yang diberikan. Kurang sosialisasi merupakan perihal yang menyebabkan anggota BPJS Kesehatan tidak mau menggunakan fasilitas kesehatan meskipun mereka dalam kondisi tidak sehat badan.

Keengganan untuk menggunakan fasilitas kesehatan yang diperoleh dari keangggotan Badan Penylenggara Jaminan Sosial Kesehatan di sebabkan memiliki referensi layanan kesehatan yang tidak baik pada masa layanan kesehatan terdahulu, seperti pada Jaminan Kesehatan Daerah ataupun Jamksemas. Anggapan masyarakat mengenai pengurusan kartu jaminan sosial di bidang kesehatan masih berbelit-belit memberikan kontribusi deskripsi layanan oleh Badan Jaminan Sosial tidak terlalu baik di mata masyarakat. Penduduk pra sejahtera di Kota Jambi belum memperoleh penjelasan secara menyeluruh tentang pemanfaatan kartu jaminan sosial kesehatan. Akan tetapi pada waktu masyarakat telah datang ke kantor Badan Penyelenggara Jaminan Sosial Kota Jambi, mereka tidak membantah bahwa keterangan yang di dapat memuaskan dan pelayanan di dapat secara baik dan sopan. Dari pihak BPJS sendiri pada saat di minta penjelasan menyebutkan bahwa mulai awal bulan Januari tahun dua ribu empat belas, anggota Badan Penyelenggara Jaminan Sosial di Kota Jambi mengalami kuantitas yang bertambah, sampai kondisi sekarang ini telah terdata satu juta orang lebih, baik yang berasal dari kategori PBI maupun non PBI.

${ }^{10}$ Wawancara dengan 97 responden yang di peroleh melalui penyebaran kuesioner melalui aplikasi google form, yang dilakukan dalam durasi bulan Nopember tahun 2020.

${ }^{11}$ Lihat kententuan Pasal 22 Ayat (1) UU Nomor 40 Tahun 2004 Tentang Sistem Jaminan Sosial Nasional 
Kemudian layanan yang disediakan oleh penyelenggara Faskes (fasilitas kesehatan) semestinya memiliki sifat responsif; pelayanan yang efektif berdasarkan dengan standar operasional dan tetap menjaga kesesuaian lama pelayanan yang akurat dan efisien. Berikut adalah alur pelayanan kesehatan dengan menggunakan kartu BPJS kesehatan:

\section{ALUR PELAYANAN KESEHATAN}

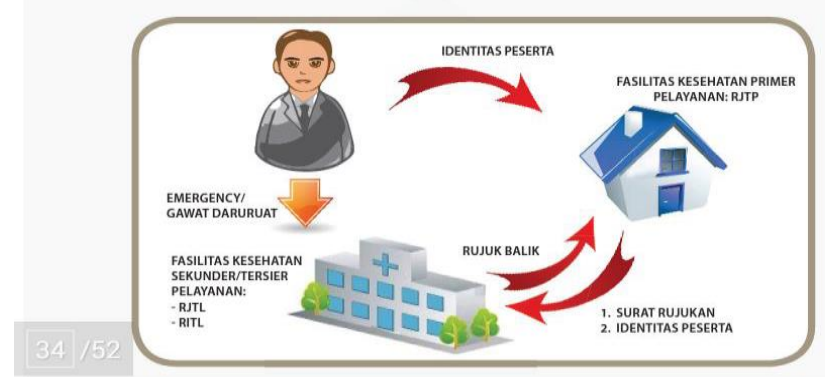

Berdasarkan alur pelayanan kesehatan di atas diharapkan kepada petugas kesehatan terutama di RS memberikan pelayanan yang sesuai dengan prosedur dan semua masyarakat harus dilayani dengan baik baik mereka pemegang kartu BPJS kesehatan kategori PBI maupun non PBI sehingga masyarakat miskin di Kota Jambi benar benar merasakan manfaat dari jaminan kesehatan nasional.

Berdasarkan hal yang di jabarkan tersebut bisa dimengerti mengenai dampak lebih jauh Jaminan Kedehatan Nasional lewat Badan Penyelenggara Jaminan Sosial kesehatan betul-betul berkorelasi terhadap layanan kesehatan bagi penduduk prasejahtera di Kota Jambi, hal ini di fahami menurut pengolahan informasi kualitatif dan atau di perkuat oleh informasi tertulis serta kondisi faktual dari aspek empiriknya berdasarkan interview dan observasi.

Memang bukan disangkal pula kelembagaan Badan Penyelenggara Jaminan Sosial memiliki pengaruh termasuk pada layanan kesehatan untuk penduduk miskin meskipun terdapat kelemahan-kelemahan lain yang juga bersifat substantif seperti aspek keramahan, kedisiplinan dan lain sebagainya. Oleh sebab itu perlu solusi terhadap persoalan tersebut di atas. Sebenarnya tidak dipungkiri bahwa terkait dengan masalah kemiskinan banyak kebijakan dan program kerja yang sudah dilakukan oleh peme-rintah walaupun dilevel central termasuk di level regional, meskipun hasilnya tidak begitu signifikan baik untuk per-baikan ekonomi, pendidikan, kesejahteraan termasuk juga jaminan kesehatan.

Perlu analisis yang komprehensif terhadap persoalan tersebut, namun setidak ada beberapa hal yang harus diperhatikan terhadap persoalan jaminan kesehatan warga miskin. Selain sosialisasi, kerjasama dan koordinasi dengan pihak luar sangat diperlukan olehkarena sampai sekarang pihak penguasa melihat dari sudut pandang mereka saja, ketika per-timbangan didapatkan dari mitra yang berlainan (Lembaga Swadaya Masyarakat/golongan penduduk) sudah jelas output-nya menjadi sangat baik. Kemitraan dan pemberdayaan masyarakat sangat diperlukan dalam hal menciptakan lingkungan hidup yang sehat baik jasmani maupun psikologis, selain itu juga diperlukan partisipasi warga untuk meningkatkan derajat kesehatan mereka.

Mengenai implementasi asas keadilan sosial bagi seluruh rakyat Indonesia, menurut penulis asas ini merupakan asas yang sifatnya sangat idiil, sebagaimana telah di sebutkan dalam penjelasan UU BPJS. Sebagai asas, asas keadilan sosial bagi seluruh rakyat Indonesia masih sangat abstrak, dapat di interpretasikan dalam berbagai sudut pandang. Sehingga asas ini dapat di kaitkan dengan asas kemanusiaan dan asas manfaat.

Akan tetapi apabila di kaitkan dengan hak semua rakyat untuk memperoleh jaminan layanan kesehatan yang pantas dan terjangkau, maka asas ini dapat di lihat dari cakupan kepesertaan masyarakat menjadi anggota BPJS. Jangkauan kenaggotaan BPJS Kesehatan di Prov. Jambi termasuk masih belum maksimal. Kuantitas masyarakat di Jambi yang telah menjadi anggota BPJS Kesehatan hingga bulan Maret tahun dua ribu sembilan belas baru mencapai 75,15\%. Kecilnya angka kenaggotaan BPJS Kesehatan tersebut mayoritas di pengaruhi kurang optimalnya sumber daya finansial layanan kesehatan masyarakat kurang mampu dari pemerintah daerah.

\section{SIMPULAN}

Berdasarkan hal yang telah di bahas penulis pada pembahasan sebelumnya, dapatlah ditarik kedalam kesimpulan bahwa di dapati permasalahan dalam pelaksanaan yang dari permasalahan keuangan, ketidakadilan klaim atas pelayanan BPJS, dan tidak meratanya sumber daya fisik, dan manusia pada fasilyas kesehatan yang terhubung dengan BPJS Kesehatan. Dengan beberapa permasalahan yang timbul tersebut dan terakit dengan asas-asas penyelenggaraan BPJS, maka kesimpulan yang diperoleh adalah bahwa asas kemanusiaan dan asas manfaat sebagian besar telah terlaksana dalam pelayanan BPJS di Rumah Sakit di Kota Jambi. Hanya Asas keadilan sosial bagi seluruh 
Pahlefi, Nelli Herlina dan Herlina Manik, Asas Penyelenggaraan Sistem Jaminan Sosial Nasional Oleh Badan Penyelenggara Jaminan Sosial (BPJS) Kesehatan di Kota Jambi

rakyat Indonesia yang masih bersifat kabur dan belum nampak pelaksanaannya pada pelaksanaan layanan kesehatan oleh Badan Penyelenggara Jaminan Sosial di fasilitas kesehatan Kota Jambi.

\section{DAFTAR PUSTAKA}

Azwar, Azrul. Program Menjaga Mutu Pelayanan Kesehatan. Jakarta: Yayasan Rosa Agustina. et.al, 2012, Hukum Perikatan (Law of Obligations) Seri Unsur-unsur Penyusun Bangunan Negara Hukum, Pustaka Larasan, Denpasar.

A. Junaedy Ganie, Hukum Asuransi Indonesia, Cet. 1 (Jakarta: Sinar Grafika, 2011).

A. Masyhur effendi, HAM Dalam/Dinamika Yuridis, Sosial, Politik, (Bogor: Ghalia Indonesia, 2010)

Abdulkadir Muhammad, Hukum Asuransi Indonesia, (Bandung: PT. citra Aditya Bakti, 2006).

Abdul Muis, Hukum Asuransi dan Bentuk-bentuk Perasuransian, Medan, Fakultas Hukum Universitas Sumatera Utara, 2005

A. djazuli dan Yadi Janwari, Lembaga-Lembaga Perekonomian Umat, (Jakarta: PT Raja Grafindo Persada, 2002).

Ali Yafie, Menggagas Figh Sosial, (Bandung: Mizan, 1994).

C.S.T. Kansil, Pokok-Pokok Pengetahuan Hukum Dagang Indonesia, (Jakarta: Sinar Grafika, 2002).

Kuat Ismanto, Asuransi Syari"ah Tinjauan Asas-asas Hukum Islam, (Yogyakarta: Pustaka Pelajar, 2009).

Rastutik, Tutik, Aspek Hukum Perjanjian Asuransi, Yogyakarta: Pustaka Yustita, 2011.

Sulastomo, System Jaminan Sosial Nasional Sebuah Introduksi,(Jakarta: PT Raja Grafindo Persada, 2008), hlm.22

Tjahjono Koentjoro, Regulasi Kesehatan di Indonesia,(Yogyakarta: ANDI OFFSET, 2007)

"Banyaknya Masalah Dalam Pelaksanaan JKN, Tindakan Pemerintah? Halaman All - Kompasiana.Com,” accessed February 24, 2020, https://www.kompasiana.com/hananisrina/5c1a8ab6ab12ae70d11c5ac3/banyak-nya-prdalam-pelaksanaan-jkn-tindakan-pemerintah?page=all\#.

Jambi Independent, "Utang BPJS Kesehatan Membeludak," JAMBIINDEPENDENT.COM, accessed February 24, 2020, https://www.jambi-independent.co.id/read/2019/11/07/44537/utang-bpjs-kesehatan-membeludak.

"Kepesertaan JKN Jambi 1,7 Juta Jiwa, BPJS Kesehatan Apresiasi Pemda Yang Daftarkan Penduduknya - Tribun Jambi," accessed February 24, 2020, https://jambi.tribunnews.com/2019/12/02/kepesertaan-jkn-jambi-17-jutajiwa-bpjs-kesehatan-apresiasi-pemda-yang-daftarkan-penduduknya\#.

https://www.cnbcindonesia.com/news/20210214114224-4-223180/bpjs-kesehatan-surplus-rp-187-t-ini-besaran-iuran2021.

Republik Indonesia, Undang-Undang Nomor 40 Tahun 2004 tentang Sistem Jaminan Sosial Nasional.

Republik Indonesia, Undang-Undang Nomor 24 Tahun 2011 Tentang Badan Penyelenggara Jaminan Sosial.

Peraturan Presiden Nomor 12 Tahun 2013 Tentang Jaminan Kesehatan 